\title{
Coupled abiotic-biotic cycling of nitrous oxide in tropical peatlands
}

Steffen Buessecker ${ }^{1 \dagger}$, Analissa F. Sarno ${ }^{1}$, Mark C. Reynolds ${ }^{1}$, Ramani Chavan ${ }^{2}$, Jin Park ${ }^{2}$, Marc Fontánez Ortiz ${ }^{1}$, Ana G. Pérez-Castillo ${ }^{3}$, Grober Panduro Pisco ${ }^{4}$, José David UrquizaMuñoz $^{5,6,7}$, Leonardo P. Reis ${ }^{8}$, Jefferson Ferreira-Ferreira ${ }^{8}$, Jair M. Furtunato Maia ${ }^{9}, 10$, Keith E. Holbert $^{11}$, C. Ryan Penton ${ }^{12}$, Sharon J. Hall ${ }^{1}$, Hasand Gandhi ${ }^{13,15}$, Iola G. Boëchat ${ }^{14}$, Björn Gücker $^{14}$, Nathaniel E. Ostrom ${ }^{13,15}$, Hinsby Cadillo-Quiroz ${ }^{1,2 *}$

${ }^{1}$ School of Life Sciences, Arizona State University, Tempe, Arizona, USA

${ }^{2}$ Biodesign Institute, Arizona State University, Tempe, Arizona, USA

${ }^{3}$ Environmental Pollution Research Center (CICA), University of Costa Rica, Montes de Oca, Costa Rica

${ }^{4}$ School of Forestry and Environmental Sciences, Ucayali National University, Ucayali, Peru

${ }^{5}$ Laboratory of Soil Research, Research Institute of Amazonia's Natural Resources, National University of the Peruvian Amazon, Iquitos, Loreto, Peru

${ }^{6}$ School of Forestry, National University of the Peruvian Amazon, Iquitos, Loreto, Peru

${ }^{7}$ Department for Biogeochemical Processes, Max Planck Institute for Biogeochemistry, Jena, Germany

${ }^{8}$ Mamiraua Institute for Sustainable Development, Amazonia, Brazil

${ }^{9}$ Normal Superior School, Amazonas State University, Manaus, Amazonia, Brazil

${ }^{10}$ National Institute of Amazonian Research, Manaus, Amazonia, Brazil

${ }^{11}$ School of Electrical, Computer and Energy Engineering, Arizona State University, Tempe, Arizona, USA

${ }^{12}$ College of Integrative Sciences and Arts, Arizona State University, Mesa, Arizona, USA

${ }^{13}$ Department of Integrative Biology, Michigan State University, East Lansing, Michigan, USA

${ }^{14}$ Applied Limnology Laboratory, Department of Geosciences, Federal University of São João del-Rei, São João del-Rei, Brazil

${ }^{15}$ DOE Great Lakes Bioenergy Research Center, Michigan State University, East Lansing, Michigan, USA

$\dagger$ Current address: Department of Earth System Science, Stanford University, Stanford, California, USA

*Correspondence to: Hinsby Cadillo-Quiroz (hinsby@asu.edu) 


\begin{abstract}
$37 \quad$ Abstract
Atmospheric nitrous oxide $\left(\mathrm{N}_{2} \mathrm{O}\right)$ is a potent greenhouse gas thought to be mainly

39 derived from microbial metabolism as part of the denitrification pathway. Here, we report that

40 in unexplored peat soils of Central and South America, $\mathrm{N}_{2} \mathrm{O}$ production can be driven by abiotic

41 reactions $(\leq 98 \%)$ highly competitive to their enzymatic counterparts. Extracted soil iron

positively correlated with in-situ abiotic $\mathrm{N}_{2} \mathrm{O}$ production determined by isotopic tracers.

Moreover, we found that microbial $\mathrm{N}_{2} \mathrm{O}$ reduction accompanied abiotic production, essentially

closing a coupled abiotic-biotic $\mathrm{N}_{2} \mathrm{O}$ cycle. Anaerobic $\mathrm{N}_{2} \mathrm{O}$ consumption occurred ubiquitously

( $\mathrm{pH}$ 6.4-3.7), with proportions of diverse clade II $\mathrm{N}_{2} \mathrm{O}$-reducers increasing with consumption

rates. Our findings show denitrification in tropical peat soils is not a purely biological process,

but rather a "mosaic" of abiotic and biotic reduction reactions. We predict hydrological and

temperature fluctuations differentially affect abiotic and biotic drivers and further contribute to

the high $\mathrm{N}_{2} \mathrm{O}$ flux variation in the region.
\end{abstract}




\section{Introduction}

The atmospheric accumulation of nitrous oxide $\left(\mathrm{N}_{2} \mathrm{O}\right)$, a potent greenhouse gas, has continued to increase $\mathrm{e}^{1,2}$, calling for a better mechanistic understanding of its sources and sinks. Tropical soils are a major source of $\mathrm{N}_{2} \mathrm{O}$. The largest contribution to global $\mathrm{N}_{2} \mathrm{O}$ flux, along with the highest uncertainties, have been observed over South America ${ }^{3-5}$ with large flux variations described in ground-based measurements from extensive peatlands of the Amazon $\operatorname{basin}^{6,7}$.

In waterlogged tropical peat soils, anoxic, reducing, humic acid-rich, and Fe-holding conditions are favorable for the abiotic formation of $\mathrm{N}_{2} \mathrm{O}^{8}$. Nitrous oxide can abiotically form from the reduction of nitrite $\left(\mathrm{NO}_{2}^{-}\right)$via intermediary nitric oxide $(\mathrm{NO})$, or hydroxylamine $\left(\mathrm{NH}_{2} \mathrm{OH}\right)^{9}$, both of which have typically low steady-state concentrations in soils.

Hydroxylamine conversion into $\mathrm{N}_{2} \mathrm{O}$ relies on oxidants such as manganese (IV) minerals that are unlikely to persist in sufficient levels in the reducing milieu of peat. Thus, peatlands would generally favor the spontaneous chemical reduction of nitrogenous compounds - also called chemodenitrification. Some environments appear to sustain abiotic $\mathrm{N}_{2} \mathrm{O}$ production rates based on dissolved $\mathrm{Fe}$ and $\mathrm{Fe}$ mineral phases ${ }^{10-12}$, while others have shown an influence from organic matter $(\mathrm{OM})^{8}$, presumably by providing complexed $\mathrm{Fe}^{2+}$ and/or humic electron shuttles ${ }^{13}$. Abiotic $\mathrm{N}_{2} \mathrm{O}$ formation has been recorded in polar ${ }^{10,14}$ and temperate ${ }^{11}$ environments, but the extent and distribution of this process in tropical peatlands have remained unexplored. With a recently estimated area of 1.7 million $\mathrm{km}^{2}$ (ref. ${ }^{15}$ ), tropical peatlands under varying climatic regimes could play a major role in global $\mathrm{N}_{2} \mathrm{O}$ gas cycling.

Denitrification, generally occurring at oxygen concentrations below $6 \mu \mathrm{M}^{16}$, is considered to be driven predominantly by microbial communities using $\mathrm{Fe}$ - and $\mathrm{Cu}$-dependent reductase enzymes ${ }^{17}$ through a modular pathway structure with different populations mediating only one or two reduction steps ${ }^{18,19}$. Denitrifying microbes are well adapted to the conditions 
found in peat soils because they anaerobically respire organic substrates using nitrogen oxides as terminal electron acceptors ${ }^{20,21}$. Also, the extensive $\mathrm{N}_{2} \mathrm{O}$ sink potential previously observed in diverse soils ${ }^{22,23}$ can be better explained with the discovery of the abundant clade II $\mathrm{N}_{2} \mathrm{O}$ reducing bacteria. While clade I $\mathrm{N}_{2} \mathrm{O}$-reducers are affiliated to the Proteobacteria, clade $\mathrm{II} \mathrm{N}_{2} \mathrm{O}$ reducers are more diverse and scattered across multiple phyla ${ }^{24}$. Interestingly, the clade II members tend to lack $\mathrm{NO}_{2}{ }^{-}$reductases more so than clade I members ${ }^{24}$. From an ecological perspective, this trait might correspond with an intrinsic capability of the soil habitat to reduce $\mathrm{NO}_{2}^{-}$via chemodenitrification. Cellular resources can be saved and relocated to the expression of $\mathrm{NO}$ and $\mathrm{N}_{2} \mathrm{O}$ reductases ${ }^{25}$ to catalyze a thermodynamically more favorable redox reaction ( $\Delta G$ of $\mathrm{N}_{2} \mathrm{O}$ reduction is $\sim 100 \mathrm{~kJ} \mathrm{~mol}^{-1}$ higher than $\Delta G$ of $\mathrm{NO}_{2}{ }^{-}$reduction).

While interactions between microbial guilds have been proposed as the basis for modularity ${ }^{23}$, the interplay of denitrifiers with abiotic reactions has received little attention, even though chemodenitrification can reduce or contribute to different inorganic nitrogen pools, including $\mathrm{N}_{2} \mathrm{O}$ and $\mathrm{NO}$. The compatibility of abiotic $\mathrm{N}_{2} \mathrm{O}$ production and modular microbial denitrification led us to hypothesize that a coupled abiotic-biotic $\mathrm{N}_{2} \mathrm{O}$ cycle could operate in tropical peatlands. To test our hypothesis, we explored the dynamics and underlying factors of abiotic $\mathrm{N}_{2} \mathrm{O}$ formation and microbial $\mathrm{N}_{2} \mathrm{O}$ reduction in six peatlands located across Central and South America using isotopic tracers. Simultaneously, we quantified and sequenced the nos $Z$ gene as a marker for the $\mathrm{N}_{2} \mathrm{O}$-reducing microbial community. Our results provide evidence for concomitant abiotic $\mathrm{N}_{2} \mathrm{O}$ production and microbial consumption active under various peat soil conditions. 


\section{Results}

97

\section{$\mathrm{Fe}^{2+}$ drives abiotic formation of $\mathrm{N}_{2} \mathrm{O}$ in high- $\mathrm{N}_{2} \mathrm{O}$ soils}

We assessed soil denitrification in six tropical peatlands, of which four were located within or near the Amazon basin (San Jorge, SJO; Melendez, MEL; Sítio do Cacau, SCB, Fazenda Córrego da Areia, FCA) and two in Central America (Medio Queso, MQE and Las Vueltas, VUL) (Fig. 1). Measured steady-state concentrations of $\mathrm{NO}_{2}^{-}$in soil pore water were below detection $(<1 \mu \mathrm{M})$ in the majority of sites, indicating rapid cycling ${ }^{26,27}$. The iron content and redox balance were highly variable, with higher $\mathrm{Fe}^{2+}$ concentrations in mountainous peat $(\sim 5 \mathrm{mM})$ and lower $\mathrm{Fe}^{2+}$ in oligotrophic peat $(0.01-0.04 \mathrm{mM})$. To determine abiotic $\mathrm{N}_{2} \mathrm{O}$ production rates under near-natural conditions, we induced a ten-fold spike with ${ }^{15} \mathrm{NO}_{2}^{-}$in-situ and measured ${ }^{14} \mathrm{~N}^{15} \mathrm{NO}+{ }^{15} \mathrm{~N}^{14} \mathrm{NO}+{ }^{15} \mathrm{~N}^{15} \mathrm{NO}$ evolution. Biotic activity was arrested by amending the soil with $87.5 \mathrm{mM} \mathrm{ZnCl}_{2}$. Because the addition of $\mathrm{Zn}$ can liberate $\mathrm{Fe}^{2+}$ ions inevitably stimulating $\mathrm{N}_{2} \mathrm{O}$ production ${ }^{8}$, we repeated the soil incubations in the laboratory, with $100 \mu \mathrm{M} \mathrm{NO}_{2}{ }^{-}$, using both gamma-irradiated and $\mathrm{Zn}$-treated peat soil. We then deduced a sitespecific correction factor for estimates of $i n$-situ rates. All our reported abiotic $\mathrm{N}_{2} \mathrm{O}$ production rates are therefore corrected for $\mathrm{Zn}$-induced $\mathrm{N}_{2} \mathrm{O}$ production. 


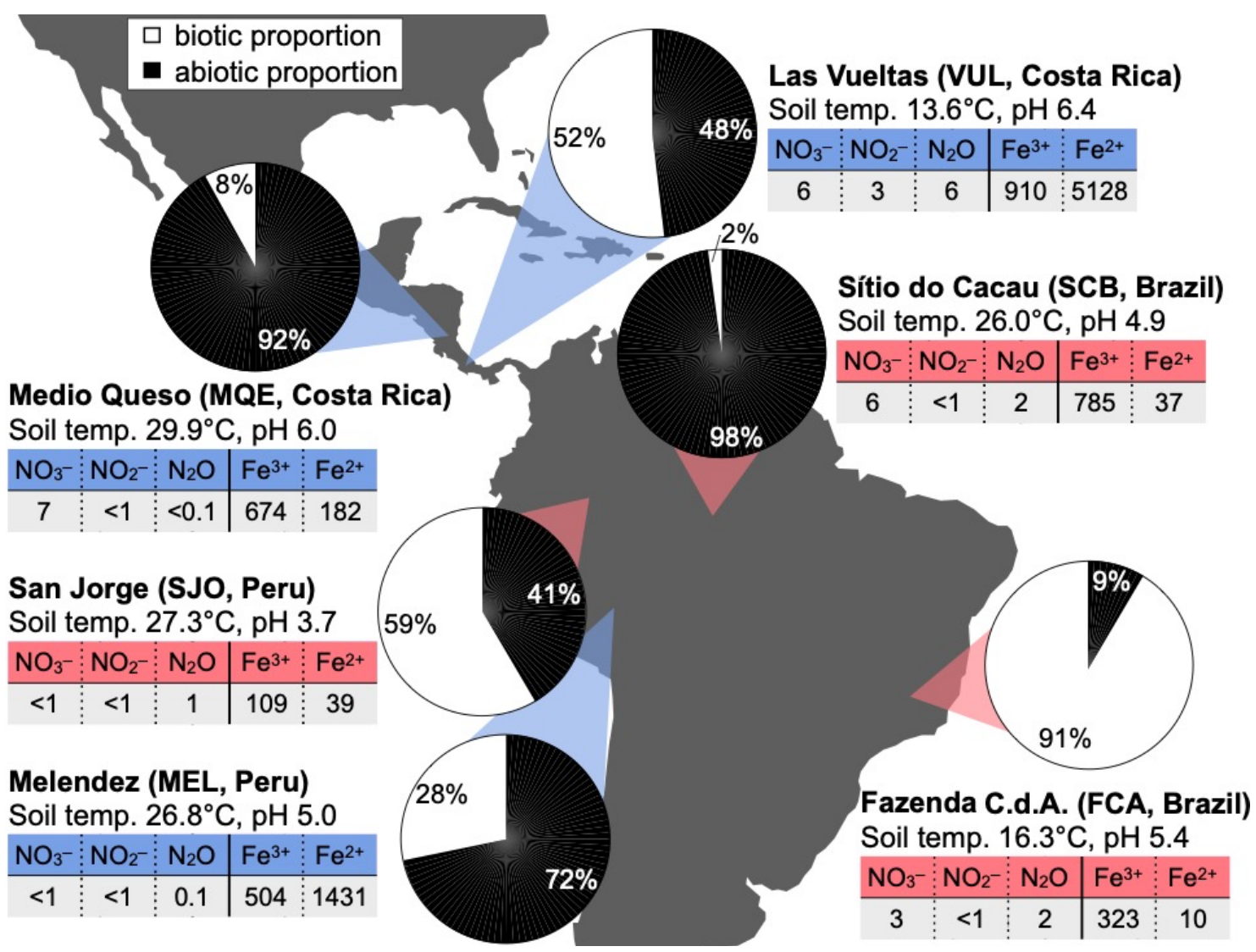

Fig. 1. Contribution of abiotic and biotic reactions to overall $\mathrm{N}_{2} \mathrm{O}$ production in tropical peatlands. Rates were derived in situ from the enrichment of ${ }^{15} \mathrm{~N}$ in $\mathrm{N}_{2} \mathrm{O}$ after addition of ${ }^{15} \mathrm{NO}_{2}{ }^{-}$to soil in the field $(\mathrm{n}=4)$. Dissolved nitrogen (measured in-situ) and Fe species (extracted) concentrations are given in $\mu \mathrm{M}$. Sites are color-coded based on their $\mathrm{NO}$ to $\mathrm{N}_{2} \mathrm{O}$ yield (Table 1), showing high-NO yield (red shades) or high- $\mathrm{N}_{2} \mathrm{O}$ yield (blue shades).

Abiotic $\mathrm{N}_{2} \mathrm{O}$ production was observed in all peatlands. In-situ rates ranged from low (0.05-0.3 nmol N $\left.\mathrm{O} \mathrm{g}^{-1} \mathrm{~d}^{-1}\right)$ at FCA and SCB, moderate (2.4-3.3 $\left.\mathrm{nmol} \mathrm{N}_{2} \mathrm{O} \mathrm{g}^{-1} \mathrm{~d}^{-1}\right)$ at MQE and SJO, and high (9.2-39.0 nmol $\mathrm{N}_{2} \mathrm{O} \mathrm{g}^{-1} \mathrm{~d}^{-1}$ ) at MEL and VUL. Abiotic $\mathrm{N}_{2} \mathrm{O}$ production contributed to the overall $\mathrm{N}_{2} \mathrm{O}$ flux to a greater extent than biotic $\mathrm{N}_{2} \mathrm{O}$ production at half the field sites (Fig. 1). Soil $\mathrm{Fe}^{2+}$ concentrations measured after extraction positively correlated with abiotic $\mathrm{N}_{2} \mathrm{O}$ production rates $\left(R^{2}=0.99, \mathrm{n}=6\right.$, Supplementary Fig. 1). To determine the nitrogen yield of the chemodenitrification reaction, we incubated gamma-irradiated peat soil under anoxic conditions with $100 \mu \mathrm{M} \mathrm{NO}_{2}{ }^{-}$, and quantified $\mathrm{NO}_{2}{ }^{-}, \mathrm{NO}$ and $\mathrm{N}_{2} \mathrm{O}$ in time (Supplementary Fig. 2). In two peatlands (SJO, SCB), complete denitrification was achieved 
almost based purely on abiotic reactions (Table 1). The transformation of $\mathrm{NO}_{2}{ }^{-}$into $\mathrm{NO}$ and

$\mathrm{N}_{2} \mathrm{O}$ resulted in dominant yields of either product across sites, suggesting unequal nitrogen diversion directed by local peat chemistry. Our analytical approach could not confirm $\mathrm{N}_{2}$ as a byproduct $^{28}$, which was presumably dominant at circum-neutral $\mathrm{pH}$ sites (MEL and VUL). We used this observed divergent $\mathrm{NO}_{2}^{-}$conversion to group the diverse peat soils into high- $\mathrm{N}_{2} \mathrm{O}$ (MQE, VUL, MEL) and high-NO (FCA, SJO, SCB) abiotic-yield sites (Table 1).

To our knowledge, this study represents the first assessment of the relative contribution of abiotic $\mathrm{N}_{2} \mathrm{O}$ production to the overall $\mathrm{N}_{2} \mathrm{O}$ production at near-natural $\mathrm{NO}_{2}^{-}$levels. Based on our results, abiotic reactions outcompete biotic reactions in three peatlands and are highly competitive as a source of $\mathrm{N}_{2} \mathrm{O}$ at another two. The measured $\mathrm{N}_{2} \mathrm{O}$ production rates were comparable to reported rates from a coniferous forest and grasslands ${ }^{29}$, although the amount of added $\mathrm{NO}_{2}^{-}$was at least one order of magnitude lower in our study. Relative to other evaluated ecosystems ${ }^{10}$, peat soils have less oxidized Fe or Mn minerals and are enriched in recalcitrant organic carbon, which would hold additional reducing power, particularly in the structurally disparate OM. For instance, pi-electron bonds are an integral part of the chemical structures found in recalcitrant organic carbon, such as phenolic or humic substances, and they are prone to interact with $\mathrm{NO}_{2}^{-}$(refs. ${ }^{30,31}$ ). Besides serving as reactants, humic substances can act as regenerable electron shuttles for redox reactions in soils and sediments ${ }^{32}$. Iron reduction and dissolution are greatly enhanced in the presence of humic substances ${ }^{33,34}$, which increases the availability of $\mathrm{Fe}^{2+}$. The distinct production of $\mathrm{NO}$ and $\mathrm{N}_{2} \mathrm{O}$ across a gradient of $\mathrm{Fe}^{2+}$ concentrations suggests divergent reaction mechanisms in high- $\mathrm{NO}$ and high- $\mathrm{N}_{2} \mathrm{O}$ soils. Previous reports agree with our data that indicate the larger production of NO as the final product of chemodenitrification, which is stimulated by the self-decomposition of nitrous acid in increasingly acidic soil milieu ${ }^{35,36}$. High- $\mathrm{N}_{2} \mathrm{O}$ soils coincided with high soil $\mathrm{Fe}^{2+}$ abundances, 
and high-NO sites were associated with low $\mathrm{Fe}^{2+}$ (Fig. 1, Table 1). Besides $\mathrm{Fe}^{2+}$, the mixture of functional groups in peat $\mathrm{OM}$ may also be crucial in determining the $\mathrm{NO}$ to $\mathrm{N}_{2} \mathrm{O}$ balance.

Except for dimethyl glyoxime and quinone oximes, oxime groups preferentially produce $\mathrm{N}_{2} \mathrm{O}$ and aromatics tend to produce $\mathrm{NO}^{37}$.

Nitrite incorporation into OM may explain lower nitrogen yields in either $\mathrm{NO}$ or $\mathrm{N}_{2} \mathrm{O}$, in addition to the possible production of $\mathrm{N}_{2}$. For example, nitrosophenol (a phenol moiety that binds one $\mathrm{NO}_{2}^{-}$ion) tautomerizes to quinone monoxime and requires another $\mathrm{NO}_{2}^{-}$ion to eject hyponitrous acid which decomposes to $\mathrm{N}_{2} \mathrm{O}^{30,31}$. Without the consecutive incorporation of 2 $\mathrm{NO}_{2}^{-}$ions, nitrosophenol remains stable, and a significant amount of $\mathrm{NO}_{2}{ }^{-}$could reside in nitrosated functional groups.

Table 1. Abiotic nitrogen yield fractions based on sterilized batch incubations. Gammairradiated peat soil was used for anoxic incubations initiated with the addition of $100 \mu \mathrm{M} \mathrm{NO}_{2}{ }^{-}$. Yield was calculated after all $\mathrm{NO}_{2}{ }^{-}$was consumed and based on stable $\mathrm{NO}$ and $\mathrm{N}_{2} \mathrm{O}$ concentrations in at least two consecutive measurements. Sites with replicated samples $(n=3)$ included: Las Vueltas (VUL), Medio Queso (MQE), Fazenda Córrego da Areia (FCA), Melendez (MEL), Sítio do Cacau (SCB), San Jorge (SJO).

\begin{tabular}{lllllll}
\hline & SCB & SJO & FCA & MEL & VUL & MQE \\
\hline Yield in $\mathrm{NO}(\%)$ & 97.2 & 92.8 & 74.3 & 0.2 & 0.2 & 1.3 \\
Yield in $\mathrm{N}_{2} \mathrm{O}(\%)$ & 4.8 & 4.8 & 4.0 & 12.1 & 24.6 & 55.9 \\
\hline Total yield (\%) & 102 & 97.6 & 78.3 & 12.3 & 24.8 & 57.2
\end{tabular}

\section{Active microbial $\mathrm{N}_{2} \mathrm{O}$ reduction in acidic peat soils}

Concomitant to $\mathrm{N}_{2} \mathrm{O}$ production, we measured $\mathrm{N}_{2} \mathrm{O}$ consumption. Only non-sterilized samples exhibited active consumption. In sterilized samples, $\mathrm{N}_{2} \mathrm{O}$ was a stable end product after $\mathrm{NO}_{2}{ }^{-}$addition, and ${ }^{15} \mathrm{~N}_{2}$ was not produced in $\left({ }^{15} \mathrm{~N}\right)_{2} \mathrm{O}$ amendments. Incubations with $\left({ }^{15} \mathrm{~N}\right)_{2} \mathrm{O}$ in the field resulted in an accumulation of the ${ }^{15} \mathrm{~N}$ label in $\mathrm{N}_{2}$ (Fig. 2) and were used to derive $\mathrm{N}_{2} \mathrm{O}$ reduction rates. Enrichment of ${ }^{15} \mathrm{~N}_{2}$ decreased with soil pH (Fig. 2), while $\mathrm{N}_{2} \mathrm{O}$ reduction was 
surprisingly observed in soils with $\mathrm{pH}$ as low as 3.7 (SJO). This finding is significant because

$\mathrm{N}_{2} \mathrm{O}$ reductase assembly is post-transcriptionally inhibited by acidic $\mathrm{pH}^{38}$, and exposure to $\mathrm{pH}<$

4 disrupts a histidine amino acid ligand to the $\mathrm{Cu}$ cofactor in $\mathrm{N}_{2} \mathrm{O}$ reductase, possibly

inactivating the catalytic function (pers. com. W. Nitschke). The measured $\mathrm{N}_{2} \mathrm{O}$ reduction rates were higher than previously observed rates at similar acidic $\mathrm{pH}$ values ${ }^{39}$ and would extend the known physiological limits for microbial $\mathrm{N}_{2} \mathrm{O}$ consumption. Thus, these results demonstrate the presence and activity of $\mathrm{N}_{2} \mathrm{O}$-reducing communities adapted to a wide range of peat soil $\mathrm{pH}$.

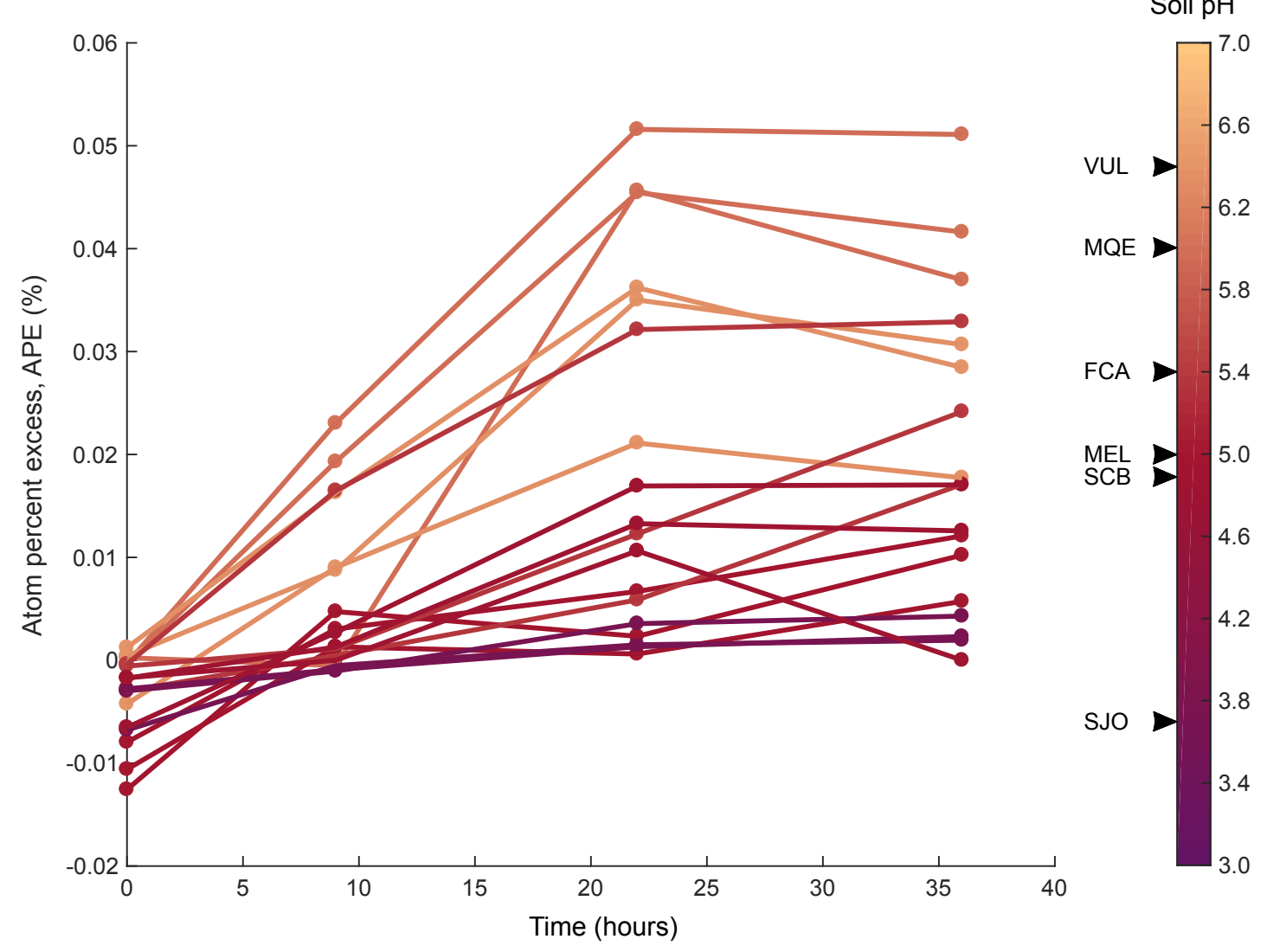

Fig. 2. Isotopic enrichment in molecular nitrogen during in-situ incubations of $\left({ }^{15} \mathrm{~N}\right)_{2} \mathrm{O}$ with anoxic peat soil. Replicates per sites $(\mathrm{n}=3)$, as listed, are colored in a gradient according to their pH. VUL, Las Vueltas; MQE, Medio Queso; FCA, Fazenda Córrego da Areia; MEL, Melendez; SCB, Sítio do Cacau; SJO, San Jorge. 

establish an increased microbial $\mathrm{N}_{2} \mathrm{O}$ sink in peatlands with high abiotic $\mathrm{N}_{2} \mathrm{O}$ fluxes.

\section{Diverse Clade II $\mathrm{N}_{2} \mathrm{O}$-reducers are associated with higher $\mathrm{N}_{2} \mathrm{O}$ sink potential}

To evaluate the relationship between the abiotic formation and microbial consumption

of $\mathrm{N}_{2} \mathrm{O}$, we compared reaction rates against nos $Z$ gene abundances. Both processes revealed

similar trends ranging from low $\left(0.1-0.3 \mathrm{nmol} \mathrm{N}_{2} \mathrm{O} \mathrm{g}^{-1} \mathrm{~d}^{-1}\right)$ in SCB and FCA to moderate (0.7-

$1.5 \mathrm{nmol} \mathrm{N}_{2} \mathrm{O} \mathrm{g}^{-1} \mathrm{~d}^{-1}$ ) in MQE and SJO to high (3-9.5 nmol N $\left.\mathrm{O} \mathrm{g} \mathrm{g}^{-1} \mathrm{~d}^{-1}\right)$ in VUL and MEL.

Consumption never outpaced production, except at two sites (FCA and MEL, Fig. 3). While the variation in nos $Z$ gene copies from both clades showed no significant differences among highNO sites (FCA, SJO, SCB), they differed (ANOVA, $p=0.05$ ) among high- $\mathrm{N}_{2} \mathrm{O}$ sites (MQE, MEL). Consumption rates gradually increased with clade II $n o s Z$ gene abundance at high- $\mathrm{N}_{2} \mathrm{O}$ sites. A clear dominance of clade II nosZ genes over those from clade I coincided with the elevated rates of $\mathrm{N}_{2} \mathrm{O}$ consumption in MEL peatland. Thus, $\mathrm{N}_{2} \mathrm{O}$ reducers from clade II

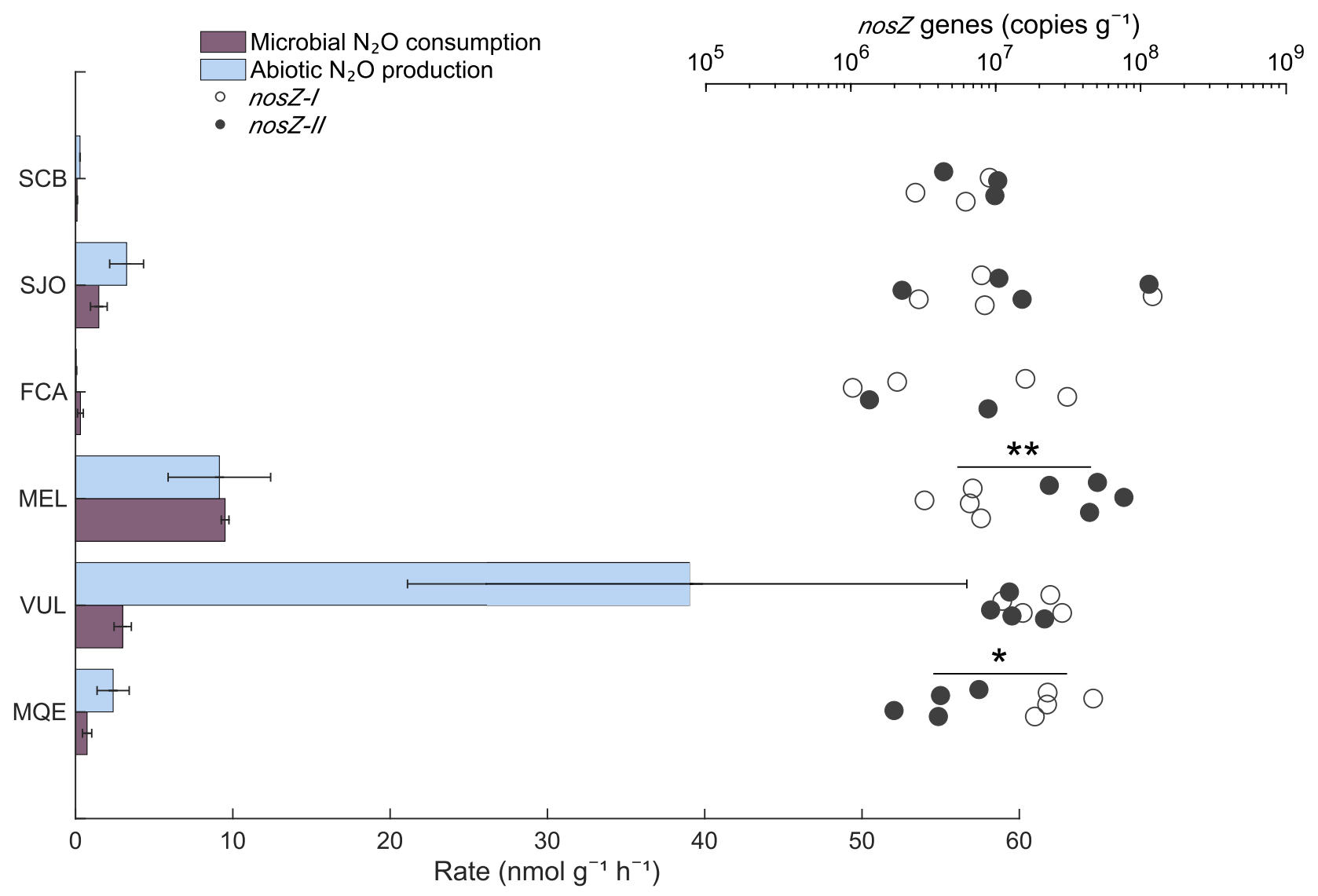


Fig. 3. Microbial $\mathrm{N}_{2} \mathrm{O}$ consumption and abiotic $\mathrm{N}_{2} \mathrm{O}$ production (bars) along with $n o s Z$ gene quantities (open and filled circles). Error bars denote $\mathrm{SD}$ (consumption rates, $\mathrm{n}=3$; production rates, $\mathrm{n}=4$ ). Clade I and II $\operatorname{nos} Z$ was quantified by qPCR assays and are significantly different within sites as denoted by asterisks (ANOVA, ${ }^{*} p=0.012,{ }^{*} p=0.008, \mathrm{n}$ =4). Two outliers for $n o s Z-I I$ (SCB, $\sim 6,200$ copies $\mathrm{g}^{-1}$; FCA, 590) are not shown and another two datapoints are missing due to non-amplification. See previous figures for site acronyms.

Next, to evaluate the $\mathrm{N}_{2} \mathrm{O}$-reducing microbial community, we analyzed 183,265 and 80,050 taxonomically assigned nos $Z$ gene amplicon sequence variants (ASVs) for clade I and II, respectively. Our analysis focused on the most abundant taxa that made up at least $1 \%$ of the total ASVs in at least one site (Fig. 4). The most abundant ASV was affiliated to the alphaproteobacterium Nitrospirillum amazonense (Fig. 4). This phylotype constituted 59-64 \% of clade I ASVs in the Amazon bogs SCB and SJO but was least represented in the MEL peatland ( $\sim 10 \%)$. In MEL, $23 \%$ of ASVs belonged to Methylocystis species, which were also abundant in FCA (27 \%). The clade II $\mathrm{N}_{2} \mathrm{O}$ reducers were more diverse (comprised more phyla) across all soils (Fig. 4), with Magnetospirillum (consistently > $10 \%$ in high-NO sites and $30 \%$ in VUL) and unclassified Myxococcales (8-50 \%) as the most abundant phylotypes. To examine the observed trend of $\mathrm{N}_{2} \mathrm{O}$ reduction rates corresponding with nos $Z$ clade II gene frequencies in the high- $\mathrm{N}_{2} \mathrm{O}$ sites (MEL > VUL > MQE, Fig. 3), we derived diversity indices and performed a principal component analysis (PCA). The Shannon diversity index showed a coinciding order of diversity levels $(1.73>1.49>1.39$, Supplementary Tables $1 \mathrm{a}-\mathrm{b})$ for high- $\mathrm{N}_{2} \mathrm{O}$ sites. This was also supported by a relatively high average Bray-Curtis dissimilarity of clade II nos $Z$ gene sequences in MEL (0.71, Supplementary Tables 1c-d), identifying the clade II $\mathrm{N}_{2} \mathrm{O}$ reducer community in this peatland as most dissimilar to all others. In addition, the community structure variation among clade II was most parsimoniously explained by $\mathrm{N}_{2} \mathrm{O}$ consumption rates in the PCA (Supplementary Figs. 3, 4). Rather than single dominant taxa, it appeared to be the contribution of a diverse group of clade II $\mathrm{N}_{2} \mathrm{O}$ reducers to be responsible for the high $\mathrm{N}_{2} \mathrm{O}$ sink potential observed. 
The intrinsic capacity of the peat to reduce $\mathrm{NO}_{2}^{-}$abiotically could provide non-

denitrifying microbes that do not possess denitrification enzymes other than $\mathrm{N}_{2} \mathrm{O}$ reductase,

called "chemodenitrifiers" ${ }^{40}$, an advantage over canonical denitrifiers. Chemodenitrifiers do not have to compete with chemodenitrification and simply harvest the end product $\mathrm{N}_{2} \mathrm{O}$ to oxidize organic substrates. Figure 4 illustrates the $\mathrm{NO}_{2}{ }^{-}$reductase (either NirS or NirK) and NO reductase (NorB) enzyme repertoires present in available reference proteomes of relatives of the predicted taxa in both clades. At least 2 out of the 11 clade I taxa (including the abundant Nitrospirillum) and 10 out of the 14 clade II taxa indicated the absence of Nir enzymes (Fig. 4). Half of the clade II reference proteomes were missing both Nir and Nor proteins. Importantly, the Myxococcales ASVs showed no differences in abundance among high-NO sites but gradually increased, similar to the $\mathrm{N}_{2} \mathrm{O}$ yield, in the high- $\mathrm{N}_{2} \mathrm{O}$ sites. This order, which also includes Anaeromyxobacter dehalogenans, the hallmark organism of clade II $\mathrm{N}_{2} \mathrm{O}$ reducers ${ }^{22,41}$, is frequently represented in acidic, organic-rich soils ${ }^{40,42}$, presumably with abiotic $\mathrm{NO}$ and $\mathrm{N}_{2} \mathrm{O}$ production potential. Further, other bacteria such as Dechloromonas ${ }^{43}$ Ardenticatena $^{44}$, and Melioribacter $^{45}$ also mediate iron reduction, an additional trait that could promote chemodenitrification by recycling $\mathrm{Fe}^{2+}$. Therefore, chemodenitrifiers may outcompete canonical denitrifiers in the studied peatlands (e.g., Nitrospirillum) and abundance patterns of the Myxococcales suggest a notable benefit for some chemodenitrifiers in soils associated with high abiotic $\mathrm{N}_{2} \mathrm{O}$ yields.

Another abundant taxon of the $\mathrm{N}_{2} \mathrm{O}$-reducing community was Magnetospirillum (clade II) that includes several iron-oxidizing species. These alpha-proteobacteria synthesize the mixed-valence iron mineral magnetite, which can accumulate in soils, also under the influence of abiotic crystallization ${ }^{46}$. Secondary iron mineral formation can be widespread in the tropics, driven by dissolved and particulate iron originating from weathering and desilication ${ }^{47-49}$. Ferrous iron-bearing minerals, such as magnetite, can serve as catalysts for $\mathrm{NO}_{2}^{-}$reduction by 
262 providing reaction sites at the mineral surface ${ }^{50,51}$. The possession of an $\mathrm{N}_{2} \mathrm{O}$ reductase makes

263 sense for Magnetospirillum, assuming cells are associated with, or at least grow in proximity to,

264 magnetite. Analyses of the iron phases present would be necessary to follow up on this in more

265 detail, which was off the scope of our study. We also acknowledge that our insight into the

266 temporal activity response is limited. Information on the actual in-situ transcription levels is

267 needed to better assess how the clades react to fluctuating abiotic pulses of $\mathrm{N}_{2} \mathrm{O}^{52}$.
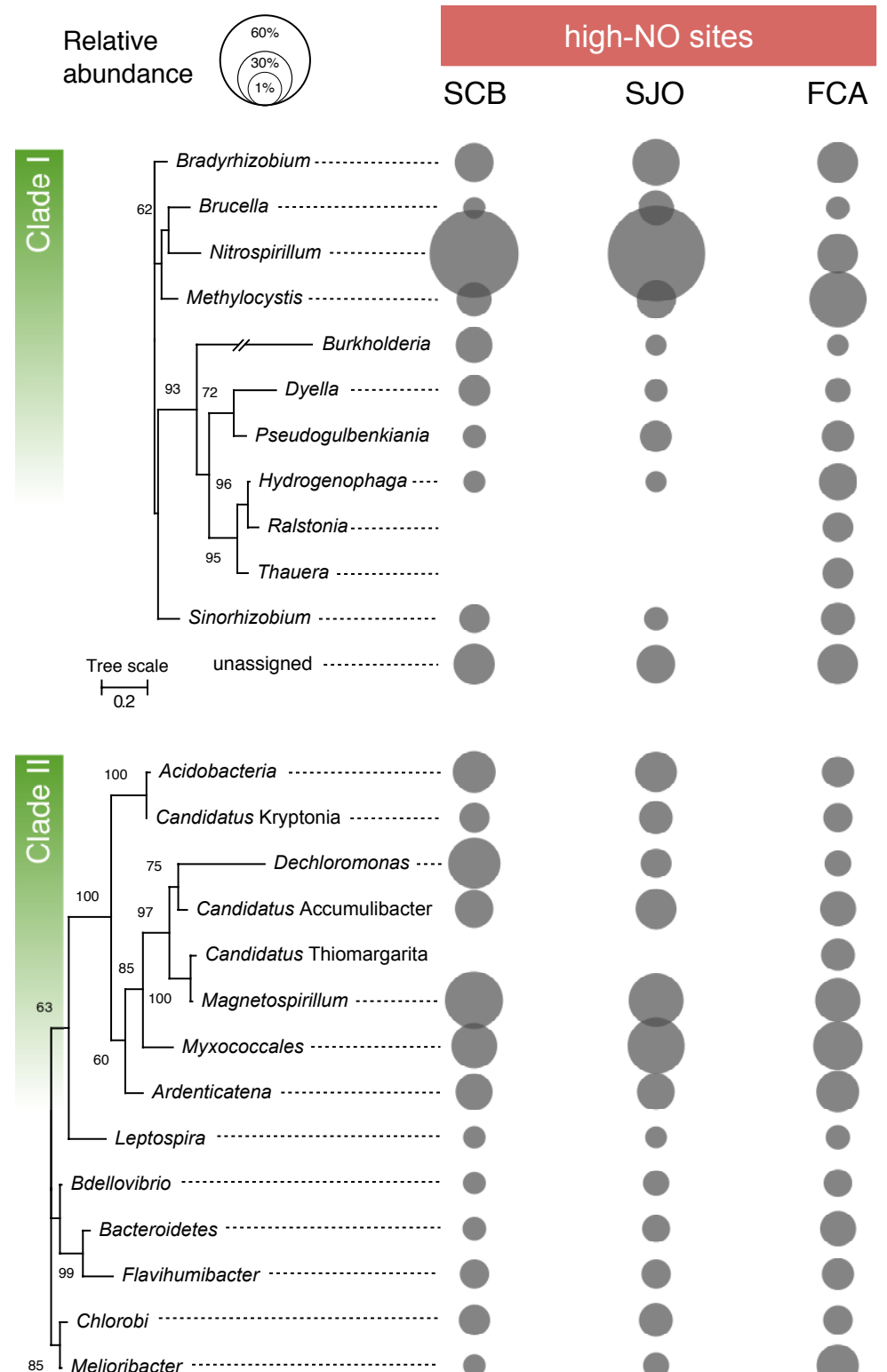

${ }_{85}$ Melioribacter -

$\stackrel{\text { Tree scale }}{\longmapsto}$

unassigned
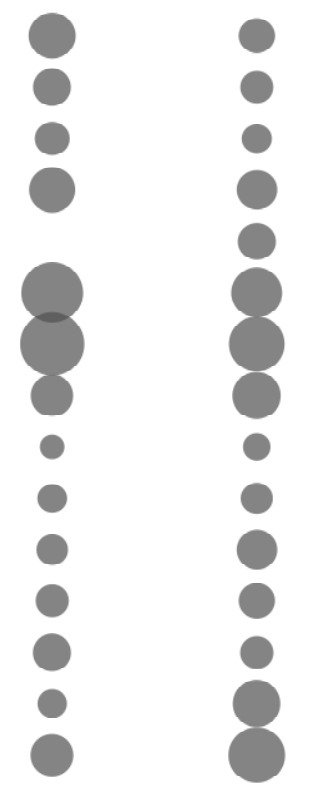
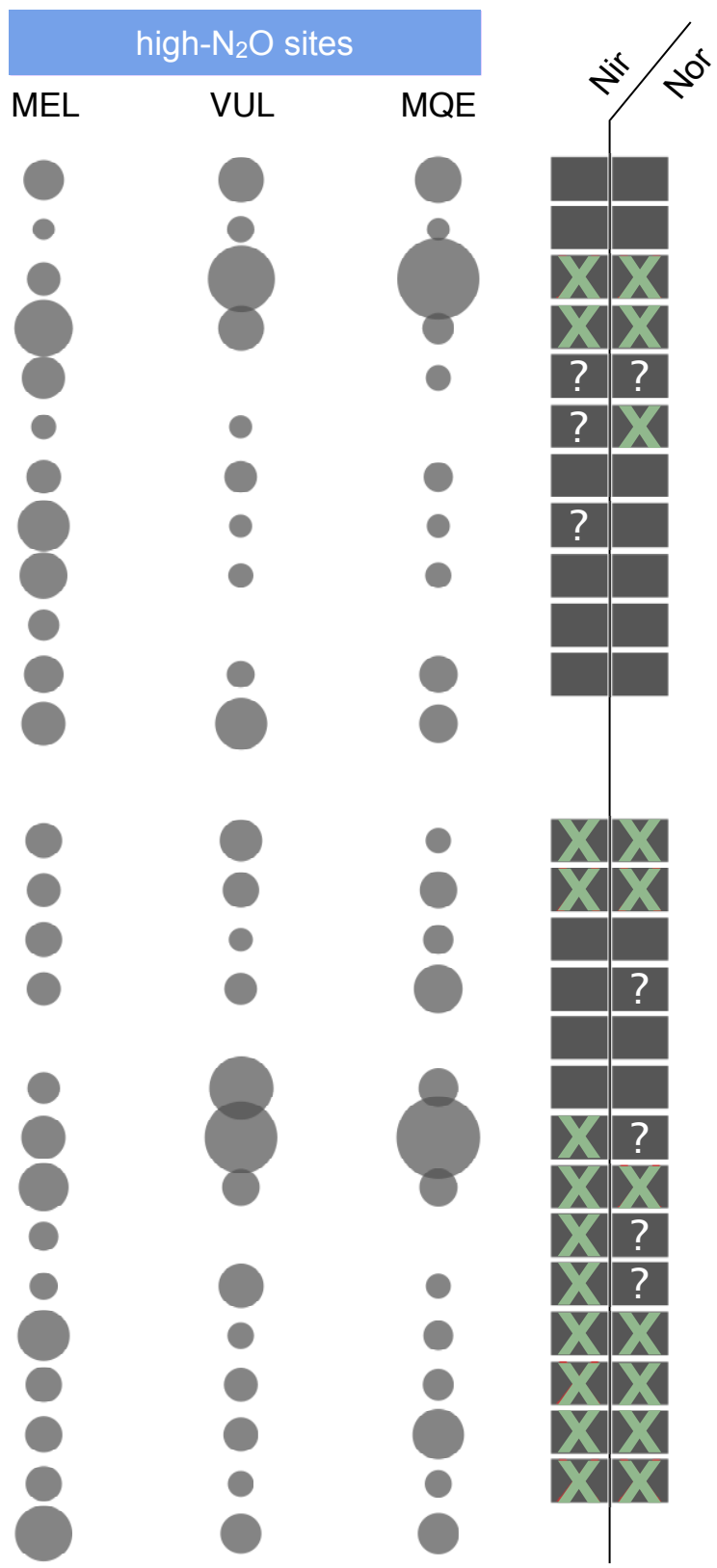
271 Fig. 4. NosZ phylogeny and taxonomy in tropical peat soils. Only the most abundant

272 amplicon sequence variants (ASVs) $>1 \%$ were included in the analysis. Maximum likelihood 273 phylogenetic trees are based on 1000 iterations. Nodes with $60 \%$ or higher bootstrap support 274 are labeled. The right panel indicates the presence (filled box) or absence (crossed box) of Nir 275 or Nor enzyme sequences in reference proteomes. Boxes with question marks indicate an 276 ambiguous distribution of Nir or Nor within the taxonomic group (Supplementary Table 2). 


\section{Discussion}

\section{Decoupling of abiotic $\mathrm{N}_{2} \mathrm{O}$ production and microbial $\mathrm{N}_{2} \mathrm{O}$ consumption}

Our data show the concomitant occurrence of both abiotic $\mathrm{N}_{2} \mathrm{O}$ production and microbial consumption (Fig. 3 and Supplementary Fig. 2), and their positive correlation points to the coupling of both processes in several sites (Supplementary Fig. 5). However, the mountain bog site (VUL) exhibited unusually high abiotic production rates and relatively low consumption rates (Fig. 3). A lower soil temperature than in the other peatlands and the differential sensitivity of production and consumption (Supplementary Table 3 and Supplementary Text) could lead to such kinetic effects ${ }^{53-55}$. Along these lines, the decoupling of production and consumption establishes the potential for vast $\mathrm{N}_{2} \mathrm{O}$ emissions when changing environmental conditions impart selectively negative effects on consumption. For instance, while peatland drainage occurs naturally between wet and dry seasons ${ }^{56}, \mathrm{~N}_{2} \mathrm{O}$ cycling could become decoupled by aerobic conditions created by extended peatland drainage with microbial denitrification persisting only in anoxic microsites. Nitrite, fueled by increased nitrification, could still be abiotically reduced to $\mathrm{N}_{2} \mathrm{O}$ because acidic peat soil stabilizes $\mathrm{Fe}^{2+}$ via two mechanisms. First, $\mathrm{Fe}^{2+}$ oxidation by oxygen is kinetically hindered at low $\mathrm{pH}$. Oxidation rates are significantly slowed at $\mathrm{pH} \leq 6.5^{57}$, a $\mathrm{pH}$ regime applying to most peatlands, including all in our study. Second, $\mathrm{Fe}^{2+}$ complexed by $\mathrm{OM}$ is resilient to oxidation. Experimental evidence suggests that tannic acid ${ }^{58}$, phenolics ${ }^{59}$, or natural humic acid ${ }^{60}$ stabilize the $\mathrm{Fe}^{2+}$ pool in the presence of oxygen by the formation of a redox-buffering shell ${ }^{60}$ and re-reduction of $\mathrm{Fe}^{3+}$. However, little is known concerning how $\mathrm{Fe}^{2+}$ complexation affects the $\mathrm{NO}_{2}{ }^{-}$accessibility and reduction. Nevertheless, these previous findings indicate that the reactants for chemodenitrification are sufficiently available even at higher oxygen concentrations $(>6 \mu \mathrm{M})$, leading to a potential predominance of abiotic $\mathrm{N}_{2} \mathrm{O}$ production over biotic $\mathrm{N}_{2} \mathrm{O}$ production. 


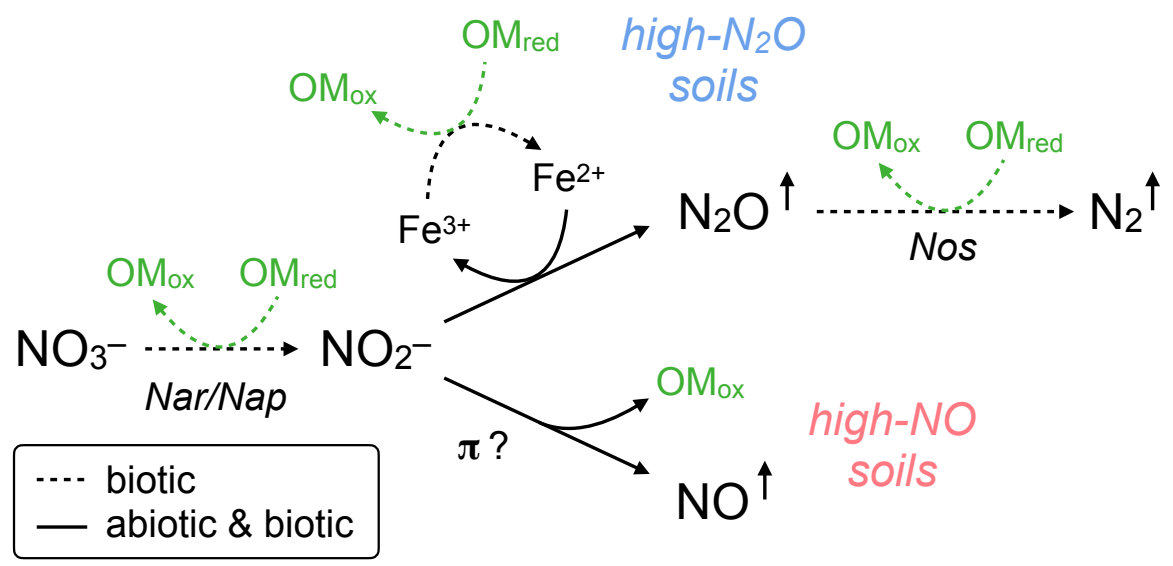

Fig. 5. Schematic representation of denitrification pathways in tropical peatlands. Nitrate $\left(\mathrm{NO}_{3}{ }^{-}\right)$reduction to $\mathrm{NO}_{2}^{-}$occurs at significant rates only with catalysis by $\mathrm{NO}_{3}{ }^{-}$reductases. Nitrite is rapidly reduced via abiotic and biotic reactions. At lower $\mathrm{pH}(\leq 5.4)$, NO is the dominant product. Nitrosation into OM may be an alternative abiotic process in soils with minor nitrogenous gas production reliant on organic compounds containing pi-electron bonds $(\pi)$. In $\mathrm{Fe}^{2+}$-rich peat, $\mathrm{N}_{2} \mathrm{O}$ is the dominant product, involving Fe redox cycling that can fuel dissimilatory Fe reduction ${ }^{11}$. The only $\mathrm{N}_{2} \mathrm{O}$ consumption pathway in peat soil is $\mathrm{N}_{2} \mathrm{O}$ reductasedependent reduction to $\mathrm{N}_{2}$, which is active even in the most acidic soils tested (pH 3.7). All related heterotrophic reactions induce oxidation of $\mathrm{OM}\left(\mathrm{OM}_{\mathrm{red}} \rightarrow \mathrm{OM}_{\mathrm{ox}}\right)$ and eventually peat carbon mineralization. peatlands, where denitrification is not a purely biological pathway, but rather a "mosaic" of biotic and abiotic reduction reactions (Fig. 5). Furthermore, our results support the idea that functional modularity complements not only the interrelationship of microbial groups but also concomitant interactions between microbes and spontaneous chemical reactions. Abiotic $\mathrm{N}_{2} \mathrm{O}$ formation in tropical peatlands can have important regional consequences in the context of observed $\mathrm{N}_{2} \mathrm{O}$ fluxes and higher rates in response to drainage ${ }^{61}$, and putatively drought ${ }^{62}$, as well as possible effects on reducing organic carbon release ${ }^{63}$. For example, compared to the other soils, abiotic $\mathrm{N}_{2} \mathrm{O}$ production was moderate in $\mathrm{SJO}$, an acidic oligotrophic site, showing a net production of $1.8 \mathrm{nmol} \mathrm{N}_{2} \mathrm{O} \mathrm{g}^{-1}$ day $^{-1}$. With the estimation of the global extent of acidic oligotrophic tropical peatlands alike SJO at $1,003,719 \mathrm{~km}^{2}$ (ref. ${ }^{15}$ ), this could amount to a total depth-integrated abiotic $\mathrm{N}_{2} \mathrm{O}$ flux ranging from 0.1 to $3.9 \mathrm{Tg}_{2} \mathrm{O} \mathrm{yr}^{-1}$ depending on the depth of $\mathrm{NO}_{2}^{-}$diffusion. This contribution is a major uncertainty that could account for two percent to 
more than half of all combined terrestrial $\mathrm{N}_{2} \mathrm{O}$ fluxes from natural sources of South America,

328 Africa, and Southeast Asia. With a factor of $298 \mathrm{~g} \mathrm{CO}_{2}$-equivalents per $\mathrm{g} \mathrm{N}_{2} \mathrm{O}$ over a 100 year time ${ }^{64}$, abiotic $\mathrm{N}_{2} \mathrm{O}$ fluxes could also alter the net radiative effect of tropical peatlands.

Accordingly, by bypassing heterotrophic respiration through chemodenitrification, less organic carbon is mineralized to $\mathrm{CO}_{2}$. Considering $~ 50 \mathrm{mg} \mathrm{CO}_{2}-\mathrm{C} \mathrm{m}^{-2} \mathrm{yr}^{-1}$ emitted from SJO-like tropical peatlands ${ }^{7}$ and 4 moles of $\mathrm{N}_{2} \mathrm{O}$ required to mineralize 1 mole of organic carbon, chemodenitrification would suppress at least $2.7 \%$ of the organic carbon mineralization, promoting the retention of $2 \mathrm{Tg} \mathrm{C} \mathrm{yr}^{-1}$ across oligotrophic tropical peatlands. These estimates are conservative because they do not include processes such as diversion of nitrogen oxides into NO, nitrosation of OM, and the consumption deficit observed in the high-altitude peatland. peatlands, which would imply an imbalanced cycling of $\mathrm{N}_{2} \mathrm{O}$ and substantial $\mathrm{N}_{2} \mathrm{O}$ release from abiotic origins. 


\section{Methods}

Study sites. Six peatlands were chosen to cover a geochemical spectrum, including acidic $(\mathrm{pH}$ 3.7-5) soils, low $(10 \mu \mathrm{M})$ and high $(>5 \mathrm{mM}) \mathrm{Fe}^{2+}$ concentrations, varying $\mathrm{OM}$ content and soil temperature (Supplementary Table 4). Most sites were under little to no anthropogenic influence (Supplementary Table 5), with two exceptions: Fazenda Córrego da Areia (FCA) located within a catchment experiencing agricultural run-off in Brazil, and Medio Queso (MQE) in a Costa Rican river delta surrounded by agricultural run-off and cattle raising. The San Jorge (SJO) peatland is located in the Pastaza-Marañón foreland basin and Melendez (MEL) is in the Madre de Dios river terraces, both in Peru. Sítio do Cacau (SCB) is located in Central Amazonia (Amanã Reserve) in Brazil. Las Vueltas (VUL), located in Costa Rica's cloud forests of the Cerro Las Vueltas Reserve, differed most drastically from the other sites due to its higher altitude (2,500 m a.s.1.). Field work was conducted in September 2017 (Peru) and between April (Costa Rica) and July (Brazil) in 2018.

\section{${ }^{15} \mathrm{~N}$ tracer experiment in the field. Colorimetric assays to determine ambient soil $\mathrm{NO}_{2}{ }^{-}$and} $\mathrm{NO}_{3}{ }^{-}$concentrations were performed in the field using a YSI 9500 portable spectrophotometer (YSI Inc.), including reagent kits, according to the manufacturer's instructions. Dissolved $\mathrm{N}_{2} \mathrm{O}$ was sampled by collecting pore water into a pre-evacuated vial and subsequent degassing by shaking for 5 minutes. Thereafter, headspace was transferred into a pre-evacuated vial and stored underwater prior to analysis with a GC-ECD. Soil temperature and $\mathrm{pH}$ were measured with a YSI A10 $\mathrm{pH}$ probe (Ecosense, YSI).

Anaerobic glove bags filled with argon (Ar) were used to provide anaerobic conditions in the field while distributing soil into glass incubation vials $(160 \mathrm{~mL})$. Topsoils $(10 \mathrm{~cm})$ were sampled with $30 \mathrm{ml}$-barrel customized plastic corers. Inside the glove bag, the center $5 \mathrm{~cm}$ ( $\sim 15$ g) soil was diluted 1:5 (w/v) into vials with anoxic water extracted directly from the deep peat 
366 soil via a water line connected to the glove bag. Separate sample sets received ${ }^{15} \mathrm{NO}_{2}^{-}$(label

367 fraction $=0.1$, Cambridge Isotopes) at $10 \times$ the soil ambient $\mathrm{NO}_{2}{ }^{-}$concentration and doubly

368 labeled $\left({ }^{15} \mathrm{~N}\right)_{2} \mathrm{O}$ (label fraction $=1.0$, Cambridge Isotopes) at $5 \times$ the soil ambient $\mathrm{N}_{2} \mathrm{O}$

369 concentration. Thus, the amount of ${ }^{15} \mathrm{~N}$ tracer applied varied slightly between sites but reflected

370 a similar order of magnitude. ${ }^{15} \mathrm{NO}_{2}{ }^{-}$incubations included untreated and $87.5 \mathrm{mM}$ zinc chloride-

371 poisoned $\left(\mathrm{ZnCl}_{2}\right.$, Fisher Scientific) soils in replicates of four $(\mathrm{n}=4)$. Soil slurries were

372 incubated in insulating containers to avoid temperature fluctuations, and gas samples were

373 taken for $\left({ }^{15} \mathrm{~N}\right)_{2} \mathrm{O}$ analysis at the beginning of incubation and after $24 \mathrm{~h}(\mathrm{n}=4)$, and for ${ }^{30} \mathrm{~N}_{2}$

374 analysis at four time points spread over $36 \mathrm{~h}(\mathrm{n}=3)$. Gas sampling was destructive (entire

375 headspace used) for $\left({ }^{15} \mathrm{~N}\right)_{2} \mathrm{O}$ analysis or by replacement with $5 \mathrm{~mL}$ Ar gas for ${ }^{30} \mathrm{~N}_{2}$ analysis. The

376 sample times for the ${ }^{30} \mathrm{~N}_{2}$ analysis were adapted from a previous study ${ }^{65}$. We also prepared zinc-

377 poisoned $\left({ }^{15} \mathrm{~N}\right)_{2} \mathrm{O}$ incubations to test for abiotic $\mathrm{N}_{2} \mathrm{O}$ consumption. The gas samples were stored

378 underwater in borosilicate glass vials closed with thick butyl rubber stoppers ${ }^{66}$ prior to analysis

379 at Michigan State University. Isotopic compositions of $\mathrm{N}_{2} \mathrm{O}$ and $\mathrm{N}_{2}$ were measured using an

380 Elementar Isoprime isotope ratio mass spectrometer (IR-MS) interfaced with an Elementar

TraceGas chromatographic system. Rate calculations closely followed a previously developed

and tested protocol ${ }^{14}$. Given the constraints of sterilant applications in the field, we repeated the

zinc-amended incubations in the lab, complementarily to incubations with gamma-irradiated

soils. The rates from both experiments were used to calculate a correction factor accounting for

artifacts caused by the zinc addition ${ }^{8}$. The rates derived in the field were then multiplied by the

and FCA have associated data from gamma-irradiated soil, but data from zinc-treated soil are

missing because of logistic issues concerning the shipment of non-sterilized (not gamma-

irradiated) soil. The final rates were combined according to the following equation for net in- 


$$
B=M+C-A
$$

where $B$ is the biotic $\mathrm{N}_{2} \mathrm{O}$ production rate, $M$ is the mixed rate (from untreated ${ }^{15} \mathrm{NO}_{2}^{-}$

incubations), $C$ is the microbial $\mathrm{N}_{2} \mathrm{O}$ consumption rate [from $\left({ }^{15} \mathrm{~N}\right)_{2} \mathrm{O}$ incubations], and $A$ is the abiotic $\mathrm{N}_{2} \mathrm{O}$ production rate (from poisoned ${ }^{15} \mathrm{NO}_{2}{ }^{-}$incubations).

Laboratory incubations. In an anoxic glove box $\left(0.1 \% \mathrm{H}_{2}\right.$ for $\mathrm{O}_{2}$ reduction in $\left.\mathrm{N}_{2}\right)$, gammasterilized and zinc-treated soil were prepared separately. Gamma sterilization followed a previous method ${ }^{8}$. Zinc chloride was applied, as described for field experiments. Roots and coarse particles ( $>5 \mathrm{~mm}$ in diameter) were removed from soils, and soils were slurried 1:5 $(\mathrm{w} / \mathrm{v})$ in anoxic, sterile $18.2 \mathrm{M} \Omega \cdot \mathrm{cm}$ water. The slurry was homogenized before equal quantities were distributed into culture vials and sealed with sterile butyl rubber stoppers. An anoxic and filter-sterilized $\mathrm{NO}_{2}{ }^{-}$solution was injected (final concentration $100 \mu \mathrm{M}$ ) into microcosms that were previously flushed with pure $\mathrm{N}_{2}$. The microcosms were agitated briefly to disperse the added substrate and then kept under dark, static conditions at room temperature for $\sim 100 \mathrm{~h}$. Dissolved $\mathrm{NO}_{2}^{-}$was quantified with the Griess reagent (Promega, Kit G2930), and NO and $\mathrm{N}_{2} \mathrm{O}$ were analyzed as described below.

Soil Fe measurements. Soils for Fe analysis were kept in anoxic serum bottles and refrigerated during transport. The species $\mathrm{Fe}^{2+}$ and $\mathrm{Fe}^{3+}$ were extracted and separated as previously described $^{8}$ and quantified in acidified aqueous solution by inductively coupled plasma-optical emission spectrometry (ICP-OES; Thermo iCAP6300 at the Goldwater Environmental Laboratory at Arizona State University). The ICP-OES pump rate for the Ar carrier was set to 50 rpm, and Fe2395 and Fe2599 lines were used for Fe quantification. Iron concentrations were determined from a calibration curve $\left(0.01-10 \mathrm{mg} \mathrm{L}^{-1}\right)$ by diluting a standard solution $(100 \mathrm{mg}$ $\mathrm{L}^{-1}$, VHG Labs, product no. SM75B-500) in $0.02 \mathrm{~N} \mathrm{HNO}_{3}$. 
$417 \quad \mathrm{~N}_{2} \mathrm{O}$ gas measurements. Using a gas-tight syringe (VICI Precision Sampling), $200 \mu \mathrm{L}$ of gas

418 sample was injected into a gas chromatograph (GC, SRI Instruments) equipped with an

419 electron-capture detector (ECD). Two continuous HayeSep-D columns were kept at $90{ }^{\circ} \mathrm{C}$

420 (oven temperature), and $\mathrm{N}_{2}$ (UHP grade $99.999 \%$, Praxair Inc.) was used as carrier gas. The

421 ECD current was $250 \mathrm{mV}$, and the ECD cell was kept at $350{ }^{\circ} \mathrm{C}$. The $\mathrm{N}_{2} \mathrm{O}$ measurements were calibrated over a range of 0.25-100 ppmv using customized standard mixtures (Scott Specialty

Gases, accuracy $\pm 5 \%$ ). Gas concentrations were corrected for solubility effects using Henry’s

law and the dimensionless concentration constant $k_{H}^{c c}\left(\mathrm{~N}_{2} \mathrm{O}\right)=0.6112$ to account for gas partitioning into the aqueous phase at $25^{\circ} \mathrm{C}$ and $1 \mathrm{~atm}^{67}$.

NO gas measurements. Nitric oxide (NO) was quantified in the microcosm headspace with a chemiluminescence-based analyzer (LMA-3D NO 2 analyzer, Unisearch Associates Inc., Concord, Canada). Headspace gas $(50 \mu \mathrm{L})$ was withdrawn with a $\mathrm{CO}_{2}-\mathrm{N}_{2}$-flushed gas-tight syringe and injected into the analyzer. The injection port was customized to fit the injection volume and consisted of a T-junction with an air filter at one end and a septum at the other end. An internal pump generated consistent airflow. Our method followed a previous protocol ${ }^{68}$, with minor adjustments. Briefly, $\mathrm{NO}$ was oxidized to $\mathrm{NO}_{2}$ by a $\mathrm{CrO}_{3}$ catalyst. The $\mathrm{NO}_{2}$ was carried across a fabric wick saturated with a Luminol solution (Drummond Technology Inc., Canada). Readings were corrected for background $\mathrm{NO}_{2}$ every 15 min (“zeroing”). Shell airflow rate was kept at $500 \mathrm{~mL} \mathrm{~min}{ }^{-1}$, and the span potentiometer was set to 8 . Measurements were calibrated with a 0.1 ppm NO (in $\mathrm{N}_{2}$ ) standard $\left(<0.0005 \mathrm{ppm} \mathrm{NO}_{2}\right.$, Scott-Marin, Riverside, and the dimensionless concentration constant $k_{H}^{c c}(\mathrm{NO})=0.0465$ to account for gas partitioning into the aqueous phase at $25^{\circ} \mathrm{C}$ and $1 \mathrm{~atm}^{67}$. 
442

443

444

Molecular analyses. Peat samples from four randomly distributed locations (coinciding with incubation locations) within a peatland were collected and frozen at $-20{ }^{\circ} \mathrm{C}$ for subsequent DNA extraction. Genomic DNA was extracted using a NucleoSpin Soil DNA extraction kit (Macherey-Nagel GmbH, Düren, Germany).

For quantitative polymerase chain reactions (qPCR), we used two primer pairs and a total reaction volume of $15 \mu \mathrm{L}$ with $1.5 \mu \mathrm{L}$ DNA template (35-50 ng genomic DNA). The clade I nosZ gene was amplified with PowerUp SYBR Green master mix (Applied Biosystems,

Foster City, $\mathrm{CA}$ ), to which $3 \mathrm{mM} \mathrm{MgCl} 2$ was added. Forward and reverse primer concentrations were $1 \mu \mathrm{M}$, and previous cycler conditions were used $^{69}$. The clade II nos $Z$ gene was amplified using SYBR Fast, ROX low master mix (Kapa Biosystems, Roche Holding AG, Basel, Switzerland), and 1.2 $\mu \mathrm{M}$ primer concentration ${ }^{70}$. Thermal cycling was initiated with 3 min of denaturing at $95^{\circ} \mathrm{C}$, followed by 40 cycles of the following stages: $30 \mathrm{~s}$ at $95{ }^{\circ} \mathrm{C}, 60 \mathrm{~s}$ at $58^{\circ} \mathrm{C}$, $30 \mathrm{~s}$ at $72^{\circ} \mathrm{C}, 30 \mathrm{~s}$ at $80^{\circ} \mathrm{C}$, and a final melting-curve. Samples were run in technical duplicates on 96-well plates using a Quantstudio 3 thermocycler (Applied Biosystems, Foster City, CA).

Standards were prepared using linearized plasmids. Standard curves indicated efficiencies of 94 $\%\left(R^{2}=0.99\right.$, nos $Z$ clade I $)$ and $85 \%\left(R^{2}=0.99\right.$, nos $Z$ clade II $)$ and melting curves showed no detectable primer dimers over the duration of 40 amplification cycles.

For Illumina amplicon sequence analysis, we developed independent nos $Z$ clade I and II libraries. PCR-amplification of both nosZ genes used the Promega GoTaq qPCR kit (Promega, Madison, WI) and $1 \mu \mathrm{L}$ of DNA template (25-50 ng genomic DNA) in a total reaction volume of $20 \mu \mathrm{L}$. Targeting the clade I nos $Z$ gene, we used a novel primer pair ${ }^{71}$. The reaction mix included $0.2 \mathrm{mg} \mathrm{mL}^{-1}$ bovine serum albumin (BSA) and $0.8 \mu \mathrm{M}$ primer concentration. For the clade II nosZ gene, we used the same primer as used for qPCR in reactions of $1 \mathrm{mg} \mathrm{mL}^{-1} \mathrm{BSA}$ and $0.8 \mu \mathrm{M}$ primer concentration. Cycling conditions for clade II nos $Z$ amplification were used 
as described ${ }^{70}$. Thermal cycling conditions for clade I nos $Z$ amplification were an initial 2 min denaturing step at $95{ }^{\circ} \mathrm{C}$, followed by 33 cycles of $95^{\circ} \mathrm{C}$ for $45 \mathrm{~s}$, annealing by $53{ }^{\circ} \mathrm{C}$ for $45 \mathrm{~s}$, and a $72{ }^{\circ} \mathrm{C}$ extension for $30 \mathrm{~s}$, and a final extension at $72{ }^{\circ} \mathrm{C}$ for $7 \mathrm{~min}$. Amplification was verified by gel electrophoresis using $1 \%$ agarose in 1 Tris-acetate-EDTA buffer. Samples were multiplexed $^{72}$, normalized (SequalPrep kit \#1051001, Invitrogen), and submitted for sequencing to the DNASU core facility at Arizona State University, with $2 \times 300$-bp paired-end Illumina MiSeq.

Paired-end sequences were merged and demultiplexed, then we used the USEARCH pipeline $^{73}$ to 1 ) correct strand orientations, 2) sort out singletons, and 3) denoise the dataset. We used alpha $=2$ for a stringent denoising of sequences ${ }^{74}$ because reads were not clustered with any identity radius to obtain ASVs. The sequences were translated and frameshift-corrected by Framebot ${ }^{75}$ with low sequence loss $(<10 \%)$. The amino acid sequences obtained were classified using Diamond ${ }^{76}$ version 0.9.25. The search was conducted in Diamond's sensitive mode, with an e-value cutoff of $10^{-5}$, resulting in the top $5 \%$ hits. Sequences were parsed through two databases; the NCBI database RefSeq (release 95) containing 146,381,777 nonredundant protein sequences and manually curated databases built from 2,817 (clade I) and 2,929 (clade II) sequences off the FunGene repository ${ }^{77}$ using the search parameters $80 \%$ HMM coverage and a minimum length of 550 amino acids. The taxonomy achieved with the curated databases was used for downstream analysis because of a higher number of classified sequences. The output was imported into Megan ${ }^{78}$ version 6.18.0, where a weighted lowest common ancestor (LCA) algorithm [default parameters according to Huson et al. ${ }^{79}$ ] was run to assign a single taxonomic lineage to each read. ASV tables were pasted into $\mathrm{Krona}^{80}$ for visual inspection of results. Reads with abundances of $>1 \%$ in at least one site were extracted, and consensus sequences were determined for each taxonomic group. Maximum-likelihood phylogenetic trees were constructed with consensus sequences in Mega $X^{81}$. To infer 
491 presence/absence of Nir and Nor enzymes in representative proteomes, UniProt reference

492 (manually curated) proteomes were screened using BlastP with default parameters. NirS

493 (Q51700, Paracoccus denitrificans PD1222), NirK (O31380, Bradyrhizobium japonicum),

494 NorB (Q51663, Paracoccus denitrificans) were used as amino acid query sequences.

495 The nos $Z$ sequences have been deposited in the GenBank, EMBL, and DDBJ databases

496 as SRA Bioproject XXX.

497

498 Statistical analyses. All statistical tests were performed with JMP Pro software (Version 13.1.0,

499 SAS Institute Inc.). Analysis of variance (ANOVA) was used with $p<0.05$ to test significantly

500 different values for gene quantities across soils. Plotting and regression analysis were done with

501 the Matlab R2018a software package (Version 9.4.0.813654, Mathworks Inc.). 


\section{References}

1. Thompson, R. L. et al. Acceleration of global $\mathrm{N}_{2} \mathrm{O}$ emissions seen from two decades of atmospheric inversion. Nat. Clim. Change 9, 993-998 (2019).

2. Tian, H. et al. A comprehensive quantification of global nitrous oxide sources and sinks. Nature 586, 248-256 (2020).

3. Zhuang, Q., Lu, Y. \& Chen, M. An inventory of global $\mathrm{N}_{2} \mathrm{O}$ emissions from the soils of natural terrestrial ecosystems. Atm. Environ. 47, 66-75 (2012).

4. Huang, J. et al. Estimation of regional emissions of nitrous oxide from 1997 to 2005 using multinetwork measurements, a chemical transport model, and an inverse method. $J$. Geophys. Res. 113, 197-19 (2008).

5. D'Amelio, M. T. S., Gatti, L. V., Miller, J. B. \& Tans, P. Regional $\mathrm{N}_{2} \mathrm{O}$ fluxes in Amazonia derived from aircraft vertical profiles. Atmos. Chem. Phys. 9, 8785-8797 (2009).

6. Teh, Y. A., Murphy, W. A., Berrio, J.-C., Boom, A. \& Page, S. E. Seasonal variability in methane and nitrous oxide fluxes from tropical peatlands in the western Amazon basin. Biogeosciences 14, 3669-3683 (2017).

7. Finn, D. R. et al. Methanogens and methanotrophs show nutrient-dependent community assemblage patterns across tropical peatlands of the Pastaza-Marañón basin, Peruvian Amazonia. Front. Microbiol. 11, (2020).

8. Buessecker, S. et al. Effects of sterilization techniques on chemodenitrification and $\mathrm{N}_{2} \mathrm{O}$ production in tropical peat soil microcosms. Biogeosciences 16, 4601-4612 (2019).

9. Heil, J., Liu, S., Vereecken, H. \& Brüggemann, N. Abiotic nitrous oxide production from hydroxylamine in soils and their dependence on soil properties. Soil Biol. Biochem. 84, 107-115 (2015).

10. Samarkin, V. A. et al. Abiotic nitrous oxide emission from the hypersaline Don Juan Pond in Antarctica. Nat. Geosci. 3, 341-344 (2010).

11. Otte, J. M. et al. $\mathrm{N}_{2} \mathrm{O}$ formation by nitrite-induced (chemo)denitrification in coastal marine sediment. Sci. Rep. 9, 1-12 (2019).

12. Jones, L. C., Peters, B., Pacheco, J. S. L., Casciotti, K. L. \& Fendorf, S. Stable isotopes and iron oxide mineral products as markers of chemodenitrification. Environ. Sci. Technol. 49, 3444-3452 (2015).

13. Stevenson, F. J. \& Swaby, R. J. Nitrosation of soil organic matter: I. Nature of gases evolved during nitrous acid treatment of lignins and humic substances. Soil Sci. Soc. Am. J. 28, 773-778 (1964).

14. Ostrom, N. E., Gandhi, H., Trubl, G. \& Murray, A. E. Chemodenitrification in the cryoecosystem of Lake Vida, Victoria Valley, Antarctica. Geobiology 14, 575-587 (2016).

15. Gumbricht, T. et al. An expert system model for mapping tropical wetlands and peatlands reveals South America as the largest contributor. Glob. Change Biol. 23, 35813599 (2017).

16. Seitzinger, S. et al. Denitrification across landscapes and waterscapes: A synthesis. Ecol. Appl. 16, 2064-2090 (2006).

17. Glass, J. B. \& Orphan, V. J. Trace metal requirements for microbial enzymes involved in the production and consumption of methane and nitrous oxide. Front. Microbiol. 3, 1-20 (2012).

18. Graf, D. R. H., Jones, C. M. \& Hallin, S. Intergenomic comparisons highlight modularity of the denitrification pathway and underpin the importance of community structure for $\mathrm{N}_{2} \mathrm{O}$ emissions. PLoS ONE 9, e114118 (2014). 
19. Roco, C. A., Bergaust, L. L., Bakken, L. R., Yavitt, J. B. \& Shapleigh, J. P. Modularity of nitrogen-oxide reducing soil bacteria: Linking phenotype to genotype. Environ. Microbiol. 19, 2507-2519 (2017).

20. Pihlatie, M., Syväsalo, E., Simojoki, A., Esala, M. \& Regina, K. Contribution of nitrification and denitrification to $\mathrm{N}_{2} \mathrm{O}$ production in peat, clay and loamy sand soils under different soil moisture conditions. Nutr. Cycl. Agroecosystems 70, 135-141 (2004).

21. Palmer, K. \& Horn, M. A. Actinobacterial nitrate reducers and Proteobacterial denitrifiers are abundant in $\mathrm{N}_{2} \mathrm{O}$-metabolizing palsa peat. Appl. Environ. Microbiol. 78, 5584-5596 (2012).

22. Sanford, R. A. et al. Unexpected nondenitrifier nitrous oxide reductase gene diversity and abundance in soils. Proc. Natl. Acad. Sci. USA 109, 19709-19714 (2012).

23. Jones, C. M. et al. Recently identified microbial guild mediates soil $\mathrm{N}_{2} \mathrm{O}$ sink capacity. Nat. Clim. Change 4, 801-805 (2014).

24. Hallin, S., Philippot, L., Löffler, F. E., Sanford, R. A. \& Jones, C. M. Genomics and Ecology of Novel $\mathrm{N}_{2} \mathrm{O}$-Reducing Microorganisms. Trends Microbiol. 26, 43-55 (2018).

25. Lycus, P. et al. A bet-hedging strategy for denitrifying bacteria curtails their release of $\mathrm{N}_{2}$ O. Proc. Natl. Acad. Sci. USA 115, 11820-11825 (2018).

26. Burns, L. C., Stevens, R. J. \& Laughlin, R. J. Determination of the simultaneous production and consumption of soil nitrite using ${ }^{15}$ N. Soil Biol. Biochem. 27, 839-844 (1995).

27. Burns, L. C., Stevens, R. J. \& Laughlin, R. J. Production of nitrite in soil by simultaneous nitrification and denitrification. Soil Biol. Biochem. 28, 609-616 (1996).

28. Wullstein, L. H. \& Gilmour, C. M. Non-enzymatic formation of nitrogen gas. 210, 11501151 (1966).

29. Liu, S., Schloter, M., Hu, R., Vereecken, H. \& Brüggemann, N. Hydroxylamine contributes more to abiotic $\mathrm{N}_{2} \mathrm{O}$ production in soils than nitrite. Front. Environ. Sci. 7, 110 (2019).

30. Thorn, K. A. \& Mikita, M. A. Nitrite fixation by humic substances nitrogen-15 nuclear magnetic resonance evidence for potential intermediates in chemodenitrification. Soil Sci. Soc. Am. J. 64, 568-582 (2000).

31. Thorn, K. A., Younger, S. J. \& Cox, L. G. Order of Functionality Loss during Photodegradation of Aquatic Humic Substances. J. Environ. Qual. 39, 1416-1428 (2010).

32. Klüpfel, L., Piepenbrock, A., Kappler, A. \& Sander, M. Humic substances as fully regenerable electron acceptors in recurrently anoxic environments. Nat. Geosci. 7, 195200 (2014).

33. Lovley, D. R. \& Blunt-Harris, E. L. Role of humic-bound iron as an electron transfer agent in dissimilatory Fe(III) reduction. Appl. Environ. Microbiol. 65, 4252-4254 (1999).

34. Kappler, A., Benz, M., Schink, B. \& Brune, A. Electron shuttling via humic acids in microbial iron(III) reduction in a freshwater sediment. FEMS Microbiol. Ecol. 47, 85-92 (2004).

35. Van Cleemput, O., Patrick, W. H. \& McIlhenny, R. C. Nitrite decomposition in flooded soil under different $\mathrm{pH}$ and redox potential conditions. Soil Sci. Soc. Am. J. 40, 55-60 (1976).

36. Van Cleemput, O. \& Baert, L. Nitrite: A key compound in N loss processes under acid conditions? Plant Soil 76, 233-241 (1984). 
37. Porter, L. K. Gaseous products produced by anaerobic reaction of sodium nitrite with oxime compounds and oximes synthesized from organic matter. Soil Sci. Soc. Am. J. 33, 696-702 (1969).

38. Liu, B., Mørkved, P. T., Frostegård, Å. \& Bakken, L. R. Denitrification gene pools, transcription and kinetics of $\mathrm{NO}, \mathrm{N}_{2} \mathrm{O}$ and $\mathrm{N}_{2}$ production as affected by soil $\mathrm{pH}$. FEMS Microbiol. Ecol. 72, 407-417 (2010).

39. Palmer, K., Biasi, C. \& Horn, M. A. Contrasting denitrifier communities relate to contrasting $\mathrm{N}_{2} \mathrm{O}$ emission patterns from acidic peat soils in arctic tundra. ISME J. 6, 1058-1077 (2012).

40. Onley, J. R., Ahsan, S., Sanford, R. A. \& Löffler, F. E. Denitrification by Anaeromyxobacter dehalogenans, a common soil bacterium lacking the nitrite reductase genes nirS and nirK. Appl. Environ. Microbiol. 84, 1-14 (2018).

41. Sanford, R. A., Cole, J. R. \& Tiedje, J. M. Characterization and Description of Anaeromyxobacter dehalogenans gen. nov., sp. nov., an Aryl-Halorespiring Facultative Anaerobic Myxobacterium. Appl. Environ. Microbiol. 68, 893-900 (2002).

42. Mohr, K. I., Zindler, T., Wink, J., Wilharm, E. \& Stadler, M. Myxobacteria in high moor and fen: An astonishing diversity in a neglected extreme habitat. MicrobiologyOpen $\mathbf{6}$, e00464 (2017).

43. Hori, T., Müller, A., Igarashi, Y., Conrad, R. \& Friedrich, M. W. Identification of ironreducing microorganisms in anoxic rice paddy soil by ${ }^{13} \mathrm{C}$-acetate probing. ISME J. 4, 267-278 (2010).

44. Kawaichi, S. et al. Ardenticatena maritima gen. nov., sp. nov., a ferric iron- and nitratereducing bacterium of the phylum 'Chloroflexi' isolated from an iron-rich coastal hydrothermal field, and description of Ardenticatenia classis nov. Int. J. Sys. Evol. Microbiol. 63, 2992-3002 (2013).

45. Podosokorskaya, O. A. et al. Characterization of Melioribacter roseus gen. nov., sp. nov., a novel facultatively anaerobic thermophilic cellulolytic bacterium from the class Ignavibacteria, and a proposal of a novel bacterial phylum Ignavibacteriae. Environ. Microbiol. 15, 1759-1771 (2013).

46. Maher, B. A. \& Taylor, R. M. Formation of ultrafine-grained magnetite in soils. Nature 336, 368-370 (1988).

47. Sanchez, P. A. Properties and management of soils in the tropics. (Wiley, 1976).

48. White, A. F. et al. Chemical weathering in a tropical watershed, Luquillo Mountains, Puerto Rico: I. Long-term versus short-term weathering fluxes. Geochim. Cosmochim. Acta 62, 209-226 (1998).

49. Hall, S. J., Liptzin, D., Buss, H. L., DeAngelis, K. \& Silver, W. L. Drivers and patterns of iron redox cycling from surface to bedrock in a deep tropical forest soil: a new conceptual model. Biogeochemistry 130, 177-190 (2016).

50. Buchwald, C., Grabb, K., Hansel, C. M. \& Wankel, S. D. Constraining the role of iron in environmental nitrogen transformations: Dual stable isotope systematics of abiotic $\mathrm{NO}_{2}^{-}$ reduction by $\mathrm{Fe}(\mathrm{II})$ and its production of $\mathrm{N}_{2} \mathrm{O}$. Geochim. Cosmochim. Acta 186, 1-12 (2016).

51. Grabb, K. C., Buchwald, C., Hansel, C. M. \& Wankel, S. D. A dual nitrite isotopic investigation of chemodenitrification by mineral-associated $\mathrm{Fe}(\mathrm{II})$ and its production of nitrous oxide. Geochim. Cosmochim. Acta 196, 388-402 (2017).

52. Drewer, J. et al. Linking nitrous oxide and nitric oxide fluxes to microbial communities in tropical forest soils and oil palm plantations in Malaysia in laboratory incubations. Front. For. Glob. Change 3, 1-14 (2020). 
53. Yvon-Durocher, G., Jones, J. I., Trimmer, M., Woodward, G. \& Montoya, J. M. Warming alters the metabolic balance of ecosystems. Philos. Trans. R. Soc. B: Biol. Sci. (2010). doi:10.1098/rstb.2010.0038

54. Yvon-Durocher, G. et al. Reconciling the temperature dependence of respiration across timescales and ecosystem types. Nature 487, 472-476 (2012).

55. Jauhiainen, J., Kerojoki, O., Silvennoinen, H., Limin, S. \& Vasander, H. Heterotrophic respiration in drained tropical peat is greatly affected by temperature - a passive ecosystem cooling experiment. Environmental Research Letters 9, 105013 (2014).

56. Wang, S., Zhuang, Q., Lähteenoja, O., Draper, F. C. \& Cadillo-Quiroz, H. Potential shift from a carbon sink to a source in Amazonian peatlands under a changing climate. Proc. Natl. Acad. Sci. USA 115, 12407-12412 (2018).

57. Stumm, W. \& Lee, G. F. Oxygenation of ferrous iron. Ind. Eng. Chem. 53, 143-146 (1961).

58. Theis, T. L. \& Singer, P. C. Complexation of iron(II) by organic matter and its effect on iron(II) oxygenation. Environ. Sci. Technol. 8, 569-573 (1974).

59. Wan, X. et al. Complexation and reduction of iron by phenolic substances: Implications for transport of dissolved Fe from peatlands to aquatic ecosystems and global iron cycling. Chem. Geol. 498, 128-138 (2018).

60. Daugherty, E. E., Gilbert, B., Nico, P. S. \& Borch, T. Complexation and redox buffering of iron(II) by dissolved organic matter. Environ. Sci. Technol. 51, 11096-11104 (2017).

61. Prananto, J. A., Minasny, B., Comeau, L.-P., Rudiyanto, R. \& Grace, P. Drainage increases $\mathrm{CO}_{2}$ and $\mathrm{N}_{2} \mathrm{O}$ emissions from tropical peat soils. Glob. Change Biol. 26, $4583-$ 4600 (2020).

62. Stirling, E., Fitzpatrick, R. W. \& Mosley, L. Drought effects on wet soils in inland wetlands and peatlands. Earth-Sci. Rev. 210, 1-15 (2020).

63. Hodgkins, S. B. et al. Tropical peatland carbon storage linked to global latitudinal trends in peat recalcitrance. Nat. Commun. 9, 1-13 (2018).

64. Arias, P. et al. Climate change 2021: The physical science basis. Contribution of Working Group I to the sixth assessment report of the intergovernmental panel on climate change. (2021).

65. Babbin, A. R., Bianchi, D., Jayakumar, A. \& Ward, B. B. Rapid nitrous oxide cycling in the suboxic ocean. Science 348, 1127-1129 (2015).

66. Hamilton, S. K. \& Ostrom, N. E. Measurement of the stable isotope ratio of dissolved $\mathrm{N}_{2}$ in ${ }^{15} \mathrm{~N}$ tracer experiments. Limnol. Oceanogr.-Meth. 5, 233-240 (2007).

67. Stumm, W. \& Morgan, J. J. Aquatic chemistry., 3rd edn (John Wiley \& Sons: New York). (1996).

68. Homyak, P. M., Kamiyama, M., Sickman, J. O. \& Schimel, J. P. Acidity and organic matter promote abiotic nitric oxide production in drying soils. Glob. Change Biol. 23, 1735-1747 (2017).

69. Henry, S., Bru, D., Stres, B., Hallet, S. \& Philippot, L. Quantitative detection of the nosZ gene, encoding nitrous oxide reductase, and comparison of the abundances of 16S rRNA, narG, nirK, and nosZ genes in soils. Appl. Environ. Microbiol. (2006). doi:10.1128/AEM.00231-06

70. Jones, C. M., Graf, D. R., Bru, D., Philippot, L. \& Hallin, S. The unaccounted yet abundant nitrous oxide-reducing microbial community: a potential nitrous oxide sink. ISME J. 7, 417-426 (2013).

71. Zhang, B. et al. A new primer set for clade I nos $Z$ that recovers genes from a broader range of taxa. Biol. Fertil. Soils 57, 523-531 (2021). 
72. Herbold, C. W. et al. A flexible and economical barcoding approach for highly multiplexed amplicon sequencing of diverse target genes. Front. Microbiol. 6, 8966 (2015).

73. Edgar, R. C. Search and clustering orders of magnitude faster than BLAST. Bioinformatics 26, 2460-2461 (2010).

74. Edgar, R. C. UNOISE2: Improved error-correction for Illumina $16 \mathrm{~S}$ and ITS amplicon sequencing. bioRxiv 081257 (2016). doi:10.1101/081257

75. Wang, Q. et al. Ecological patterns of nifH genes in four terrestrial climatic zones explored with targeted metagenomics using Framebot, a new informatics tool. mBio 4, e00592-13 (2013).

76. Buchfink, B., Xie, C. \& Huson, D. H. Fast and sensitive protein alignment using DIAMOND. Nat. Methods 12, 59-60 (2015).

77. Fish, J. A. et al. FunGene: the functional gene pipeline and repository. Front. Microbiol. 4, 1-14 (2013).

78. Huson, D. H. et al. MEGAN Community Edition - Interactive exploration and analysis of large-scale microbiome sequencing data. PLoS Comput. Biol. 12, e1004957 (2016).

79. Huson, D. H. et al. MEGAN-LR: New algorithms allow accurate binning and easy interactive exploration of metagenomic long reads and contigs. Biol. Direct 13, 1-17 (2018).

80. Ondov, B. D., Bergman, N. H. \& Phillippy, A. M. Interactive metagenomic visualization in a Web browser. BMC Bioinform. 12, 1-10 (2011).

81. Kumar, S., Stecher, G., Li, M., Knyaz, C. \& Tamura, K. MEGA X: Molecular evolutionary genetics analysis across computing platforms. Mol. Biol. Evol. 35, 15471549 (2018). 


\section{Data availability}

All data to evaluate the conclusions of the study are present in the paper and the Supplementary Information.

\section{Acknowledgments}

We acknowledge Dr. Rodil Tello Espinoza, Dr. Tedi Pacheco Gomez, David Reyna, Brian Crnobrna, Dr. Outi Lähteenoja, Kelsen Arbaiza, Antenor Hurtado Carmona, Paulo Fonteboa, Ronaldo César Chaves, Juan Rodrigo Trucios, Cely Mariela Cadillo-Quiroz, the UFSJ Graduate Program in Geography (PPGEOG) and Office for International Affairs (ASSIN/UFSJ) for assistance and help during stages of field work. We also thank Wolfgang Nitschke (CNRS/BIP) for discussions and Mohamed Abdalla for his work supporting this effort at the USAID-GDR program at ASU.

This study was primarily funded by an NSF-DEB award (\#1355066) and a SOLS -KED ASU award (ECR A548 HC) to H.C-Q, a Global Development Research Scholarship to S.B. and H.C-Q in partnership with the USAID-Global Development Lab and Peruvian and Brazilian USAID missions. S.B. also received support by the Lewis \& Clark Fund for Exploration and Field Research in Astrobiology provided by the American Philosophical Society (APS). N.E.O. was funded in part by the DOE Great Lakes Bioenergy Research Center (DOE BER Office of Science DE-SC0018409).

\section{Author contributions}

S.B., N.E.O., and H.C.-Q. designed the study. S.B. conducted the field work with essential contributions from A.G.P-C, G.P.P., J.D.U.-M., L.P.R., J.M.F.M., I.G.B., and B.G.. S.B., M.F.O., A.F.S., and M.C. R. performed laboratory experiments and molecular analyses. S.J.H. supported the NO analysis. K.E.H. conducted soil gamma sterilization. C.R.P. supported qPCR analysis. H.G. analyzed isotopic abundances of gas samples. S.B., I.G.B., B.G., N.E.O., and H.C.-Q. performed the data analysis. S.B. and H.C.-Q. wrote the manuscript, and all co-authors contributed to the final version of the paper.

\section{Competing interests}

The authors have no competing interests to declare. 